In this issue:

\section{Education for Community} College Librarianship

San Francisco

Conference Highlights . . . 271

Highlights of ACRL

Board Meetings . . . . . . 275

View from $\mathrm{HQ} \ldots \ldots \ldots \ldots .277$

ACRL Officers . . . . . . . . 279

ACRL Chapters $\ldots \ldots \ldots \ldots 282$

Continuing Education:

$\mathrm{CE}$ and the Information

Environment ........285

Copyright Controversy . . . . . 286

News from the Field . . . . . 290

People . . . . . . . . . . . . . 294

Publications $\ldots \ldots \ldots \ldots \ldots 304$

Calendar . . . . . . . . . 306

Classified Advertising ......308 vey of $1968 .{ }^{2}$ Veit reported on information elicited from forty-two schools; fifty schools responded to the current questions.

In 1968 , Veit reported that there were no library schools offering a course designed specifically for students preparing for community college librarianship, and that only two schools were planning seminars on this topic. In 1980 (keeping in mind that some schools have moved away from type-of-library approaches), six schools reported the availability of such a course. Thirty-six additional schools offer a course in academic librarianship which covers the community college library. At least half of these schools also offer courses in specialized areas identified by both Edsall $^{3}$ and Matthews ${ }^{4}$ as being important for study by future community college librarians. Such courses would include: "Non-book Materials," "Design and Production of Instructional Materials," "Design and Production of Media," "Instructional Technology," "Instructional Technology Administration," "Media and Services for Adults," "Multimedia Practicum," "Media Centers: Theoretical Foundations," "The DistrictRegional Media Center," and "The Library in the Community," as reported by the responding schools. Three schools encourage students to enroll in general education courses in "The Community College"; several have a special practicum for community college experience as well. Three schools also report special credit-free programs related to community college librarianship at the master's or post-master's level, whereas Veit re-

\section{Video Involvement for Libraries}

Susan Spaeth Cherry, editor

College \& Research Libraries News (ISSN 0099-0086) is published by the Association of College and Research Libraries, a division of the American Library Association, as 11 monthly (combining July-August) issues, at $50 \mathrm{E}$. Huron St. Chicago, IL 60611. Annual subscription: \$10, or to members of the division, $\$ 2.50$, included in dues. Single copies and back issues, $\$ 3.50$ each. Second-class postage paid for at Chicago, Illinois, and at additional mailing offices.

Editor: George M. Eberhart, ACRUALA, 50 E. Huron St. Chicago, IL 60611; (312) 944-6780. President ACRL: David C Weber Executive Director, ACRL Julie Carroli Virgo

Production and circulation office: $50 \mathrm{E}$. Huron St. Chicago, IL 60611. Display advertising should be sent to Leona Swiech Advertising Traffic Coordinator, ALA, at above address. Send classified ads to ACRL. Change of address and subscription orders should be addressed to College \& Research Libraries News, for receipt at the above address at least two months before the publication date of the effective issue.

Inclusion of an article or advertisement in C\&RL News does not constitute official endorsement by ACRL or ALA

A partial list of the services indexing or abstracting the contents of C\&RL News includes: Current Contents: Social \& Behavior Sciences; Current Index to Journals in Education: In formation Science Abstracts; Library \& Information Science Abstracts; Library Literature; and Social Sciences Citation Index.

To the postmaster: Please send undeliverable copies to ACRL, 50 E. Huron St., Chicago, IL 60611.

(C)American Library Association 1981. All material in this journal subject to copyright by the American Library Association may be photocopied for the noncommercial purpose of scientific or educational advancement.

\begin{abstract}
A compilation and update of the series of articles on video that appeared in American Libraries between April 1979 and October 1980, a series designed to explore the educational and informational possibilities of the medium and to show how to use it effectively.

Emphasis is placed upon recorders, cable TV, videodisc players, and computer-linked information, describing what has been done successfully with them in school media centers and in public and academic libraries. It reports the latest developments in home information systems, such as videotext and teletext, gives techniques of camera work, and lists the software and services that are available for program planners.
\end{abstract}

84p. ISBN 0-8389-0323-1 (1981) $\$ 6.00$

Order Department

American Library Association

50 E. Huron Street, Chicago, IL 60611 
ported only two in 1968.

While it must be noted that, as in Veit's study, the contributions by other educational agencies and library schools not on the ALA list were not examined, nevertheless the developments in 1980 indicate some progress in increasing both the visibility and the educational opportunities in community college librarianship. Even with the combination of only modest growth ${ }^{5}$ and normal staff attrition, new community college librarians with specialized training, as suggested by Matthews and Edsall, will still be needed. At the same time we cannot expect all students to come

'Damon D. Hickey, "The Impact of Instructional Technology on the Future of Academic Librarianship," in Academic Libraries by the Year 2000 , ed. by Herbert Poole (New York: Bowker, 1977), pp. 34-39.

${ }^{2}$ Fritz Veit, "Training the Junior College Librarian," Journal of Education for Librarianship 9 (Fall 1968): 108-115.

${ }^{3}$ Charles Hale \& Shirley Edsall, "The Education of Community College Librarians," Journal of Education for Librarianship 16 (Fall 1975): 75- to library science programs with a comprehensive knowledge of different types of library employment possibilities. If we wish to continue and/or increase the visibility of community college librarianship as an option for new entrants to librarianship, then we must turn to a new set of questions-" What role should community college librarians, either individually or through their associations, take in the promotion of their specialty to future entrants into librarianship?" and "How can new partnerships with library educators be formed so that this visibility and educational opportunity is insured?"

\section{5.}

${ }^{4}$ Elizabeth W. Matthews, "Update in Education for Community College Library Administrators," Journal of Education for Librarianship 19 (Spring 1979): 304-31I.

${ }^{5}$ See information about enrollment projections in community colleges in Nancy B. Dearman \& Valena White Plisko, eds., The Condition of Education: Statistical Report 1980 (Washington: U.S. Department of Education, National Center for Educational Statistics, 1980), p. 24.

\section{San Francisco Conference Highlights}

San Francisco lived up to its reputation as the "Air-Conditioned City" by greeting conferencegoers with beautiful, cool weather. Despite the distance from the hotels to the Civic Auditorium, librarians kept a busy schedule of meetings, programs, tours, and informal discussions.

Among the conference events were tours of the City College of San Francisco and the Mission College LRC, excursions to local wineries, and nearly twenty program meetings. The excitement of annual conference was enhanced by hundreds of excellent San Francisco restaurants, art museums, the magic of Chinatown and Fisherman's Wharf, an incredible Gay Freedom Day Parade, the clear Pacific air, and the distant mountains.

\section{ACRL's Program Meeting}

On June 28 many members attended the membership meeting and program at the SheratonPalace Hotel. Penny Abell, 1980-81 ACRL President, launched the program theme of "Scholars and Librarians: Partners in Learning and Research" with some introductory observations, explaining: "During my tenure as ACRL president, I have attempted to concentrate my efforts on fostering closer relationships between academic librarians, individually and collectively, and their counterparts in higher education and research. Such interaction is crucial to the provision of adequate library and institutional support."
The theme speaker, Laura A. Bornholdt, vicepresident for education of the Lilly Endowment, spoke on "Shaking the Foundations" and provided some insight into what it is like to work for a foundation. She also suggested some ways in which librarians might expand their circle of foundation friends in the next ten years.

Afterwards, three pairs of librarian/scholar panelists reviewed their experiences with funded projects. John White, professor of philosophy and religion at DePauw University, described the ARL/OMS Small Library Development Project and remarked that "a good self-study team demands a good deal of trust and willing contributions on the part of both teaching faculty and librarians." A bibliographic instruction program for chemistry majors at the University of Rochester

\section{Dues Increase Referendum Passed}

ACRL members voted in favor of increasing ACRL divisional dues an additional $\$ 10$ in the July ballot. The final count as of July 30 , 1981 , was 1,320 votes for the increase, and 1,103 against, representing a 55\%-45\% approval.

The new rates will go into effect with the 1982 membership year. 